UDC 621.7

DOI: $10.31471 / 2415-3184-2019-1(19)-104-110$

\author{
D. Dimitrijević Jovanović ${ }^{I}, P$. Živković ${ }^{1}$, \\ J. Janevski ${ }^{1}$, M. Vukić ${ }^{1}$, A. Momčilović ${ }^{1}$, \\ D. Jovanovic ${ }^{2}$ \\ ${ }^{1}$ Innovation Centre of Advanced Technologies, \\ University of Nis, Nis, Serbia \\ ${ }^{2}$ Public Utility Company Waterworks, Leskovac, Serbia
}

\title{
GREEN LIVING ROOF SIMULATION MODEL REVIEW
}

The integration of nature, living, organic materials, in the design of built areas and building structure is an architectural response to the environmental problems of dense urban areas. At the site where green space is limited, greening the building envelope is the solution to the issues such as heat waves, flooding, and noise and air pollution. The benefits could be predicted only by using the accurate simulation model of this technology. The energy balance of green living roof has been researched through the models developed over the years by various authors. Most models have been developed and validated with data from extensive roofs and more than $50 \%$ of the models have been validated using data from warm temperate climatic zones. The ability to determine the impact of green living roofs at different stages of their architectural design process is of most importance if the incorporation of this technology is planned, taking into account the impact on the building and the urban level.

Only five of more than twenty models have been implemented in the building energy simulation programs, such as EnergyPlus, TRNSYS, ESP-r, and MIT. Still, not all of these GLR models are part of the software's official release. The largest differences between the models were in the ways each mass and heat transfer phenomenon was considered. The lack of appropriate and easy-to-use building energy simulation that integrates GLR models complicates the evaluation of the green roof performance at the early stages of the building design process or the optimization of the green roof design at this stage and assessment of the impact on the building and the urban level. The validations of these models differ and do not follow any particular protocol or standard. Unfortunately, no study has reported the whole-building energy data to evaluate the impacts of green living roofs on the energy consumption of buildings and no study has compared and validated more than one model at a time. Consequently, it is difficult to evaluate which model is more accurate in terms of the actual energy performance of buildings.

Keywords: green roof, simulation, model, building.

Introduction. Living architecture is the integration of the living, organic systems characterized by green walls and green roofs, with the inorganic and lifeless structures that have come to dominate modern architecture. Green roof technology, as an architectural tool, originated in Germany in the 1880s, although, the history of green roof in the form of roof gardens started in Babylon around 500 B.C. Germany is regarded as the world leader in the employment of green roof strategy with the greenest roofs in the world and as the country with the most advanced knowledge in modern living roof technology. Green-roof coverage in Germany alone now increases by approximately 13.5 million square meters per year. According to the latest studies conducted by FBB (Fachvereinigung Bauwerksbegrünung), 80\% of implemented green roofs are extensive type. According to ADIVET (French association of green roofing companies), from $100,000 \mathrm{~m}^{2}$ to $1,000,000 \mathrm{~m}^{2}$ of green roofs have been implemented yearly in France for the past ten years. Green roofs in London cover $9300 \mathrm{~m}^{2}$ only in the Greater London area. In the US, Chicago is a leading city in green roofs technology with more than $50,000 \mathrm{~m}^{2}$ of installed vegetative roofs only in 2008. In Canada, the city of Toronto approved the by-law mandating of green roofs on residential and industrial buildings. From February 1, 2010 to March 1, 2015, 260 green roofs were created in Toronto, consisting of $196,000 \mathrm{~m}^{2}$ of green roof area. Serbia and the surrounding countries are late in practical work as well as research due to the constraint from infrastructure investment, lack of relevant laws, regulations and national policies concerning the green roof strategy.

There has been a substantial development in designing and constructing green vegetated roofs. Green roofs offer several substantial benefits in comparison to conventional roofs. Recent papers offer a complete review of the main environmental benefits that green roofs can achieve, such as providing reduction in stormwater runoff and improving stormwater quality, reducing interior noise levels, reducing dust and air pollution levels, increasing thermal efficiency. Depending on the types of plants and soils, a 
green roof can provide the natural habitat for animals, insects and plants and can increase the biodiversity of the urban area and, at the city level, contribute to the mitigation of the urban heat island effect [1].

Results and discussion. There are two main classifications of green roofs: Extensive Green Roofs (EGR) and Intensive Green Roofs (IGR). Each system is defined primarily by the depth of the growth media, but also by the variety and type of vegetation. In the recent literature, Semi-intensive Green Roof occurs as a hybrid system, composed of both Extensive and Intensive Green Roof characteristics.

Extensive Green Roofs (EGR). Extensive Green Roofs are lightweight structures with a thinner substrate and feature succulent plants like sedums that can survive in harsh conditions. They are used mostly for environmental benefit, require little maintenance once they are established and are generally cost effective, particularly in commercial and public buildings with long life spans.

Intensive Green Roofs (IGR). Intensive Green Roofs allow a great variety of sorts and sizes of plants, such as shrubs and small trees, but have higher initial costs. A thicker soil layer should be considered as a landscape with plants found in parks and gardens and requires irrigation during dry periods. The thicker soil requires greater structural support for intensive roofs, than for the extensive ones.

Green Living Roof (GRL) assembly. Green roof construction mimics in a few centimeters what normal soil does in a couple meters, as shown in Fig. 1. The green roof accomplishes natural balance through several layers.

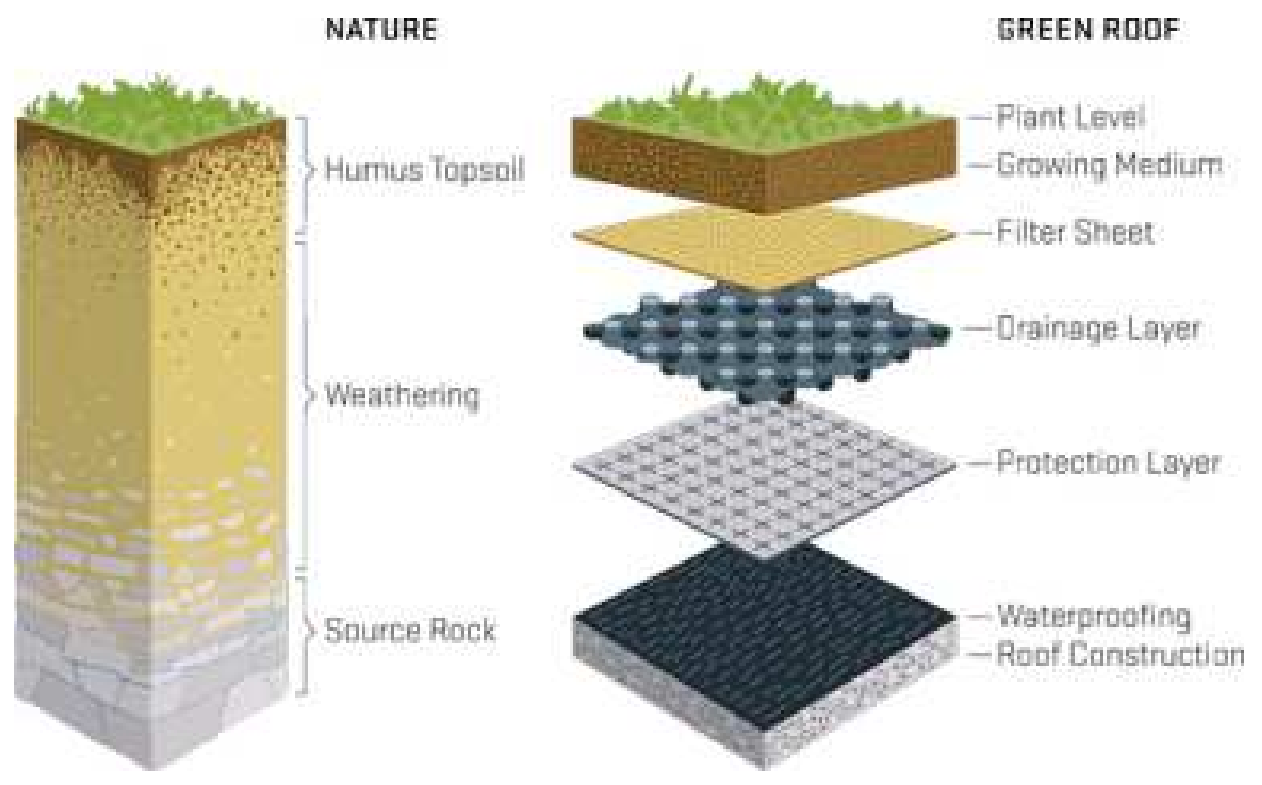

Fig. 1. Green roof systems mimics the natural soil layers

Three main components of the model of the green vegetated roof are:

1) The Structural Support includes all the layers between the inner plaster and the root barrier;

2) The Soil Layer, also called substrate, growth medium or engineered soil, is a complex with the solid phase (organic and mineral material), the liquid phase (water) and the gaseous phase (water vapor and air). Engineered soil is a substitution for standard landscaping soil or loam containing a specified ratio of the organic and inorganic material. When applying Green Living Roofs to existing buildings, the growth media must be designed with consideration of the load capacity of the roof structure.

3) The Foliage Layer (vegetation canopy) is composed of the leafs and the air within the leafs and depends on the plant selection. The plant's architecture, such as leaf size, shape and coverage, and physiology, for example, transpiration tendencies, will affect the roof's performance and its tolerance to drought, wind, light, shade, and pollutants. The selection criteria of the plants should be performed according to the particular GLR application with account of the climate conditions and maintenance requirements of the plants.

Several more layers could be present, depending on its complexity. As a part of structural support, besides slab, we can identify:

1) Insulation Board. The insulation in a GLR system requires sufficient compressive strength to support the weight of the full saturated soil and water storage, hardscape materials, live loads and environmental loads. 
2) Protection Board. It is required as fire separation and protection between the selected waterproofing membrane and insulation board.

3) Waterproofing Membrane. Fluid-applied asphalt-based membranes, torch-applied bitumen membranes, thermoplastic (PVC or TPO) single-ply membranes, or thermoset polymer-based (EPDM) single-ply membranes could be installed in the GLR assembly.

4) Root Barriers are commonly made of thermoplastic sheets such as PVC, TPO or polyethylene. Asphalt-based and bituminous membranes and materials are subject to attack and premature degradation from soil-borne microbial activity; therefore, root barriers are necessary to protect these waterproofing materials and eliminate the risk of root penetration into the waterproofing membrane.

5) Drainage Panel has the function to expel excess water from the roof during rain periods, which can easily pass underneath it away and down the roof drain. It also serves as water storage for the GLR during dry periods, providing water for the upper layers in relatively small space and with light weight. It can be manufactured from a variety of materials, including hard plastic, polystyrene, and foam, or made from free-draining materials, such as gravel.

6) Filter Fabric is a woven or non-woven geotextile which provides protection against the accumulation of fine soil in the drainage paths, ensuring the long-term efficiency of the drainage layer.

7) Moisture Retention Mat performs the dual functions of retaining water to provide moisture for the growing media and the plants and protecting the waterproof membrane during and after construction. This layer is very often made of recycled polypropylene fibers stitched to a thermoplastic fabric sheet, such as polyethylene.

The accurate and validated heat and mass transfer models are crucial to evaluate the energy performance of buildings. In most studies the analyzed Foliage Layer design parameters were the height of plants, the leaf area index (LAI), leaf reflectivity, leaf emissivity and stomata resistance and the analyzed thermal properties of the Soil Layer were thickness, density, thermal conductivity, and heat capacity. The numerical and field studies showed that Thermal insulation also plays an important role in the performance of vegetated roofs.

Green Living Roof (GRL) numerical heat and mass transfer simulation models. Many green living roof simulation models have been developed during the last 35 years. Most of the models have been developed during the last decade. General assumptions have been applied to most of the reviewed models, for example:

1) Horizontal heat and mass transfer are negligible.

2) Plants and substrate of the vegetated roofs are horizontally homogeneous.

3) Volumetric water content within the substrate is homogeneous.

4) Green roof substrate is completely covered by plants.

5) Conductive heat transfer in plants is negligible.

6) Photosynthesis of the plant results in negligible heat fluxes.

7) Air beneath the stomata is saturated.

More than 20 models could be found in the current literature. Nevertheless, only a few numerical heat and mass transfer green roof models have been implemented in actual energy building simulation tools. There are four building energy simulation engines that include green living roof models: EnergyPlus, TRNSYS, ESP-r and MIT Design Advisor.

EnergyPlus is an energy analysis and thermal load simulation program that has its roots in two other simulation programs, both written in Fortran: BLAST (Building Loads Analysis and System Thermodynamics) and DOE-2, developed by the U.S. Department of Energy. The GRL model developed by Sailor [2] is implemented in the official version of the software. Moreover, the model from TabaresVelasco et al. [3] has been implemented, but is currently not part of the official release version.

The energy balance of the green roof is dominated by radiative forcing from the sun. This solar radiation is balanced by the sensible (convection) and latent (evaporative) heat flux from soil and plant surfaces combined with the conduction of heat into the soil substrate and long-wave (thermal) radiation to and from the soil and leaf surfaces. Sailors [2] energy budget analysis follows the fast all season soil strength (FASST) model developed by Frankenstein and Koenig [4] for the US Army Corps of Engineers. The energy budget was divided into a budget for the foliage layer $F_{f}(1)$ and a budget for the ground surface $F_{g}(2)$.

$$
F_{f}=\sigma_{f}\left[I_{s}\left(1-\alpha_{f}\right)+\varepsilon_{f} I_{i r}-\varepsilon_{f} \sigma T_{f}^{4}\right]+\frac{\sigma_{f} \varepsilon_{g} z \sigma}{\varepsilon_{1}}\left(T_{g}^{4}-T_{f}^{4}\right)+H_{f}+L_{f},
$$




$$
F_{g}=\left(1-\sigma_{f}\right)\left[L_{s}\left(1-\alpha_{g}\right)+\varepsilon_{g} I_{i m}-\varepsilon_{g} T_{g}^{4}\right]+\frac{\sigma_{f} \varepsilon_{g} \delta^{\sigma}}{s_{1}}\left(T_{g}^{4}-T_{f}^{4}\right)+H_{g}+L_{g}+K \times \frac{\partial T_{g}}{g z},
$$

where $\sigma_{f}$ - fractional vegetation coverage; $F_{f}$ - net heat flux to foliage layer $\left[\mathrm{W} / \mathrm{m}^{2}\right] ; I_{s}-$ total incoming short-wave radiation; $\alpha_{f}$ - albedo of the canopy; $\alpha_{g}$ - albedo of ground surface; $\varepsilon_{f}$ - emissivity of canopy; $\varepsilon_{g}$ - emissivity of the ground surface; $I_{i r}$ - total incoming long-wave radiation; $T_{f}$ - foliage temperature $\left[{ }^{\circ} \mathrm{C}\right] ; \sigma$-Stefan-Boltzmann constant; $T_{g}$ - ground surface temperature $\left[{ }^{\circ} \mathrm{C}\right] ; H_{f}$ - foliage sensible heat flux $\left[\mathrm{W} / \mathrm{m}^{2}\right] ; H_{g}-$ ground sensible heat flux $\left[\mathrm{W} / \mathrm{m}^{2}\right] ; L_{f}-$ foliage latent heat flux $\left[\mathrm{W} / \mathrm{m}^{2}\right] ; L_{g}-$ ground latent heat flux $\left[\mathrm{W} / \mathrm{m}^{2}\right]$.

Complex Tabares-Velasco model is given in Fig 2.

A proposed green roof model was validated using the quasi-steady state experimental data. All heat fluxes in GLR system were supposed to be interconnected and dependent on each other, hence the model considered heat and mass transfer processes between the sky, plants, and substrate. Several different models were calculated: substrate thermal conductivity, the substrate and plants evapotranspiration, radiative heat transfer between the plants and substrate, and convection heat and mass transfer.

GRL model [5] integrated in TRNSYS is not part of the official TRNSYS package/type, but it was validated with the field data for vegetated walls and roofs in mock-up buildings. The mathematical model, describing energy balance across the green roof, was based on the model of Frankenstein and Koenig [4] and Sailor [2]. Water balance was introduced through the term of thermal conductivity, which was not taken into account in the previous model.

The equation describing the mass transfer of water is:

$$
C_{m} \frac{D_{\psi}}{\partial t}=\frac{D_{\psi}}{\partial z}\left[D_{m} \frac{D_{\psi}}{\partial z}-D_{l \psi}\right]
$$

where $C_{m}$ is the capillary capacity of the soil, $\psi$ is the matrix potential of water in the soil (m), $D_{m \psi}$ and $D_{l \psi}$ are respectively the water conductivity (liquid and vapor) and liquid water related to the potential gradient (m s-1).

ESP-r is an open-source building energy program commonly used in Europe, in which two green roof models are adopted [6,7]. Currently simulation domains include thermal exchanges, moisture transfer, and air flows within and across zones, HVAC plants, electrical distribution, and piping networks. The building geometry, fabric and zones are represented by control volumes. The statement of energy balance for the rooftop layer was expressed in terms of seven energy fluxes and the heat capacity of the roof layer was given as [6]:

$$
S W_{\text {down }}-S W_{\text {up }}+L W_{\text {down }}-L W_{u p}-Q_{\text {convection }}-Q_{\text {conduction }}-\mathrm{Q}_{\text {latent }}=C_{\text {roof }} \frac{d T_{\text {roof layer average }}}{d t}
$$

where $S W, L W, Q_{\text {convection, }}, Q_{\text {conduction }}, Q_{\text {latent }}$ refer to shortwave, longwave, convection, conductive heat flow (into or from the room below) and latent heat transport, respectively.

The method in [7] used for the development of green roof model involved dividing the green roof elements into control volumes and identifying the governing thermal and moisture exchange equations. These equations were further turned into a set of time-discretized equations which were solved for successive time steps. The control volume equations were combined and the matrix of linear equations was formed for facilitating the simultaneous solving for state variables. The time varying coefficients of these matrix equations were defined in terms of thermal and moisture-related properties of various elements of the green roof.

MIT Design Advisor, an early-stage building design program, has a GLR model developed by Ray and Glicksman [8]. The assumed energy balance for the green roof with insulation under the slab is shown in Fig. 3.

They took into consideration the convective, $H_{v e g}$, shortwave radiation, $I_{s}(1-\rho)\left(1-\tau_{s}\right)$, and longwave radiation, $q_{i r, v e g}$, heat transfer between the vegetation and environment, and a latent $L_{v e g}$, as well. The only interaction between the vegetation and soil is assumed to take place through longwave radiation, $q_{i \text { r, soil-veg, }}$, although the soil interacts with the environment by receiving incident solar radiation $I_{s}(1-\rho) \tau_{s}$ as well as by exchanging longwave radiation, $q_{i r}$, soil. Heat is conducted through the soil, slab, and insulation, denoted $q_{\text {conduct }}$ and convection, $H_{\text {room }}$, and raditation, $q_{i r \text {, room }}$ as heat transfer to the room. The green roof model was validated by both the University of Kobe and FSEC studies. 


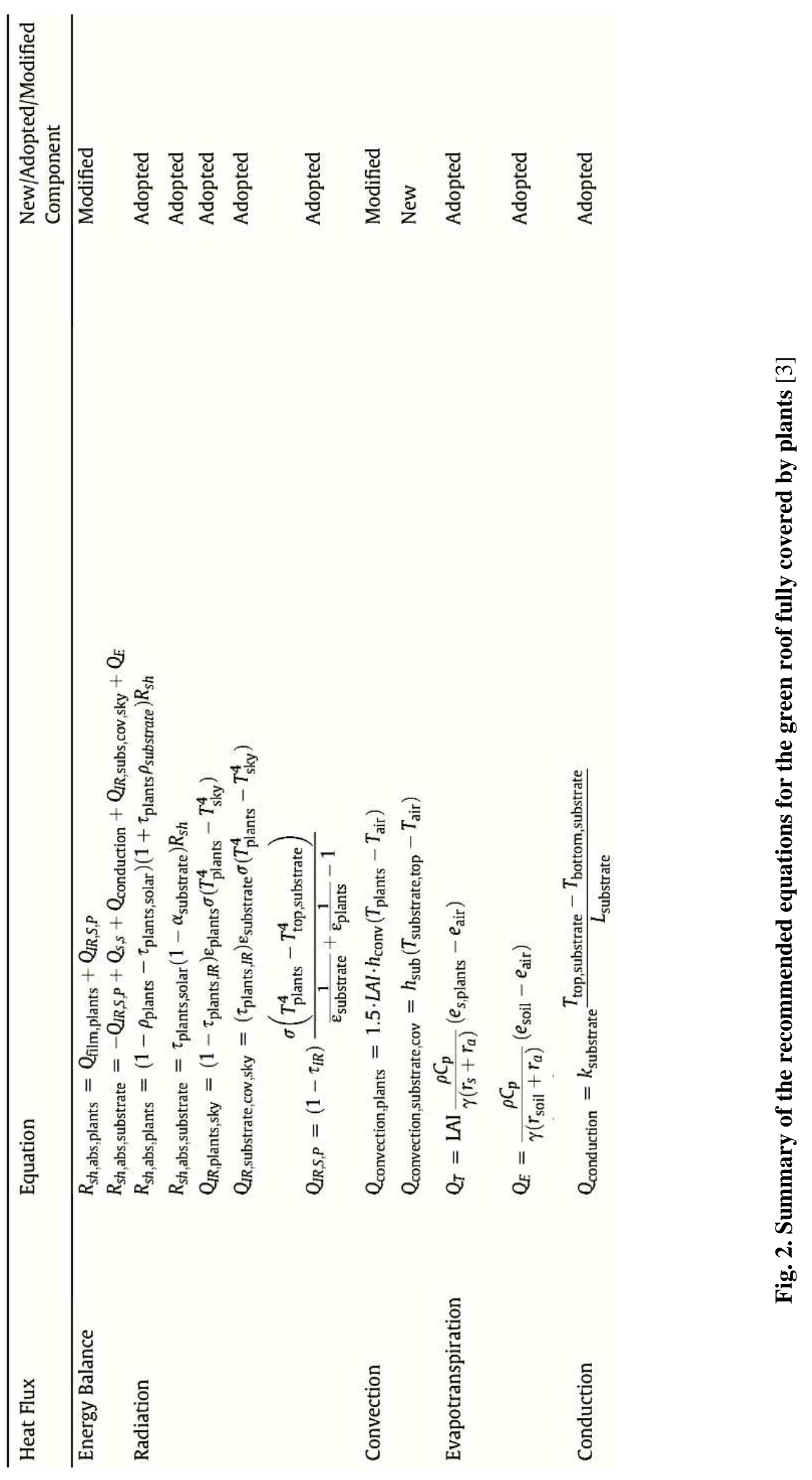




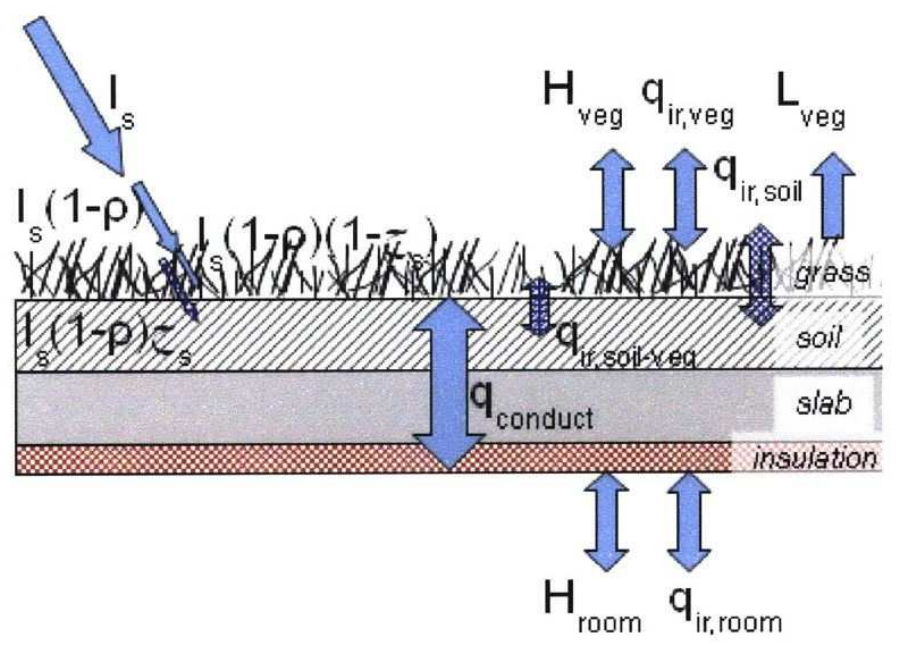

\section{Fig. 3 Green roof energy balance. All terms shown are energy fluxes [8]}

Conclusions. Only five of more than twenty models have been implemented in the building energy simulation programs, such as EnergyPlus, TRNSYS, ESP-r, and MIT. Still, not all of these GLR models are part of the software's official release. The largest differences between the models were in the ways each mass and heat transfer phenomenon was considered. The lack of appropriate and easy-to-use building energy simulation that integrates GLR models complicates the evaluation of the green roof performance at the early stages of the building design process or the optimization of the green roof design at this stage and assessment of the impact on the building and the urban level. The validations of these models differ and do not follow any particular protocol or standard. Unfortunately, no study has reported the whole-building energy data to evaluate the impacts of green living roofs on the energy consumption of buildings and no study has compared and validated more than one model at a time. Consequently, it is difficult to evaluate which model is more accurate in terms of the actual energy performance of buildings.

\section{Д. Димитрієвич Йованович ${ }^{1}$, П. Живкович О. Яневськи , М. Вукич Г. Момчилович ${ }^{1}$, Д. Йованович \\ ${ }^{1}$ Інноваційний центр передових технологій, Університет Ніш, Ніш, Сербія \\ ${ }^{2}$ Комунальне підприємство “Waterworks”, Лесковаи, Сербія}

\section{ОГЛЯД ІМІТАЦЙНОї МОДЕЛІ ЗЕЛЕНОГО ДАХУ}

Інтеграція природи, живих, органічних матеріалів, при проектуванні забудованих територій $\mathrm{i}$ будівельних конструкцій $є$ архітектурною відповіддю на екологічні проблеми густонаселених міських територій. На місці, де обмежені зелені насадження, озеленення зовнішньої оболонки будівлі є вирішенням таких питань, як теплові хвилі, затоплення, шум і забруднення повітря. Переваги цієї технології можна передбачити лише за допомогою точної імітаційної моделі. Енергетичний баланс зеленого даху досліджено крізь призму моделей, розроблених різними авторами протягом багатьох років. Більшість моделей розроблено та підтверджено даними 3 екстенсивних дахів, і більш ніж 50\% моделей перевірено з використанням даних 3 помірно-теплих кліматичних зон. Можливість визначення впливу зелених дахів на різних етапах їхнього архітектурного проектування має найбільше значення, якщо застосування цієї технології заплановано з урахуванням її впливу на будівлю і міський рівень.

Лише п'ять 3 більш ніж двадцяти моделей було реалізовано у програмах моделювання енергоспоживання будівлі, таких як EnergyPlus, TRNSYS, ESP-r i MIT. Проте не всі з цих моделей зеленого даху є частиною офіційного випуску програмного забезпечення. Найбільші відмінності між моделями полягали у тому, як було розглянуто кожне явище тепло- і масообміну. Відсутність належного та простого у використанні моделювання енергоспоживання будівлі, що інтегрує моделі зеленого даху, ускладнює оцінку ефективності зеленого даху на ранніх етапах процесу проектування будівлі або оптимізацію проекту зеленого даху на цьому етапі та оцінку впливу на 
будівлю на рівні міста. Підтвердження цих моделей відрізняються і не відповідають певному протоколу або стандарту. На жаль, у жодному дослідженні нема інформації про енергетичні дані цілої будівлі для оцінки впливу зелених дахів на енергоспоживання будівель, у жодному дослідженні не здійснено порівняння і не підтверджено більше ніж одну модель за один раз. Отже, важко оцінити, яка модель більш точна у контексті реальної енергетичної ефективності будівель.

Ключові слова: зелений дах, імітаційне моделювання, модель, будівництво.

\section{References}

1 Berardi, U., Ghaffarian, H. A., A comprehensive analysis of the environmental benefits of green roofs, Applied Energy, 115 (2014), pp. 411-428;

2 Sailor DJ. A green roof model for building energy simulation programs. Energy Build 2008;40(8):1466-78;

3 Tabares Velasco PC. Predictive heat and mass transfer model of plant-based roofing materials for assessment of energy savings Ph.D. Thesis Department of Architectural Engineering, The Pennsylvania State University; 2009;

4 S. Frankenstein, G. Koenig, FASST Vegetation Models, U.S. Army Engineer Research and Development Center, Cold Regions Research and Engineering Laboratory (ERDC/CRREL), Technical Report TR-04-25, 2004;

5 Ouldboukhitine SE, et al. Assessment of green roof thermal behavior: a coupled heat and mass transfer model. Build Environ 2011;46(12):2624-31;

6 Gaffin SR, et al. Energy balance modeling applied to a comparison of green and white roof cooling efficiency. Third annual international greening rooftops for sustainable communities. Washington, D.C.: Green Roof for Healthy Cities; 2005;

7 Decruz A. Development and integration of a green roof model within whole building energy simulation. Ph.D. Thesis. Nottingham, UK: University of Nottingham; 2016;

8 Ray S, Glicksman L. Potential energy savings of various roof technologies. Thermal Performance of the Exterior Envelopes of Whole Buildings XI International Conference. Clearwater Beach, FL: ASHRAE; 2010.

Надійшла до редакиії 20 травня 2019 р. 